\title{
DISCURSO DE POSSE NA TITULARIDADE DO DEPARTAMENTO DE DIREITO PENAL, MEDICINA FORENSE E CRIMINOLOGIA
}

\author{
Antonio Luis Chaves Camargo \\ Professor Titular do Departamento de Direito Penal \\ da Faculdade de Direito da Universidade de São Paulo
}

\begin{abstract}
Exmo. Sr. Professor Titular,
Doutor Guido Fernando da Silva Soares,

DD. Vice-Diretor desta Faculdade de Direito da USP,

Digno Presidente da Mesa
\end{abstract}

Autoridades:...

Prezados e Eminentes Docentes que compõem esta Colenda Congregação da Faculdade de Direito da USP,

Prezados Senhores,

Agradeço as palavras amáveis e carinhosas do meu amigo e eminente colega, Professor Titular Guido Fernando da Silva Soares, fruto de sua amizade e sensibilidade.

Desejo, também, agradecer o apoio sempre inestimável dos colegas do Departamento de Direito Penal, Medicina Forense e Criminologia, na pessoa de seu chefe atual, Professor Titular Miguel Reale Júnior, pelo apoio constante para que pudéssemos atingir este cargo nesta Faculdade de Direito.

Desejo agradecer, em especial, os eminentes Desembargadores Carlos Renato de Azevedo Ferreira, Digníssimo Presidente da Academia Paulista de Magistrados; Desembargador José Rodrigues de Carvalho Netto e Desembargador Marco Antonio Marques da Silva, que nos deram um apoio inestimável, participando ativamente desta Solenidade, que é organizada pela Direção da Faculdade de Direito da USP.

Cumprimento meu colega, Professor Titular Sérgio Pinto Martins, que nesta oportunidade também toma posse no cargo de professor titular do Departamento de Direito do Trabalho; 
E, finalmente, agradeço o apoio que sempre recebi dos alunos do pósgraduação e da graduação, bem como de todos os funcionários desta Faculdade de Direito.

Neste momento, quando tomo posse, solemente, no cargo de Professor Titular de Direito Penal, nesta Faculdade de Direito, de renome internacional, sinto a responsabilidade de uma função, que, se é árdua, é, também, confortante.

Árdua, no seu dia-a-dia, na exigência de dedicação e confortante porque tem a vida e energia positiva dos jovens, sempre em busca de um saber que lhes permita uma atividade profissional, nesta complexa sociedade de conhecimento em que vivemos.

Nesta, como é o caso do Brasil, o Direito vive uma crise que nos deixa atônitos e ao mesmo tempo nos leva a buscar caminhos que nos possibilitem encontrar soluções que atendam as reividicações de cada um, na concretização deste Estado Democrático de Direito. Há, ainda, o sério compromisso de tornarmos realidade a dignidade da pessoa humana, fundamento deste mesmo Estado Democrático de Direito.

Há necessidade de superarmos a metodologia até então aplicada pela nossa ciência jurídica e buscarmos em países mais avançados as inspirações para aplicarmos, de acordo com nossa cultura jurídica, os novos métodos proporcionados pela Filosofia e pela Sociologia Jurídica .

Esta atitude de coragem nos transformará em verdadeiros cientistas do Direito e pesquisadores, alicerces para a construção de um País melhor e adequado aos novos tempos.

Temos que ter consciência de que a sociedade atual é a sociedade do medo, da dúvida do estresse, mas, ao mesmo tempo, há pontos positivos e cabe à educação o poder de transformar as negatividades em fatores de desenvolvimento e crescimento intelectuais

O homem está num processo de busca desenfreada de si mesmo. Não vislumbra no seu horizonte os valores morais que o façam sentir-se digno e os éticos que lhe permita conviver em paz com o próximo.

A violência paira em cada ato, em cada gesto, em cada comunicação, e aqueles que buscam a paz, também não a encontram nos instrumentos.jurídicos disponíveis de controle social. Tudo faz parecer um caos.

Entretanto, há esperança, e esta está bem próxima de cada um de nós. Aos docentes é reservada a missão mais importante que é a de ensinar, a formação nãosó cultural, mas também moral e ética 


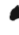

A arte de ensinar demonstra que nenhum mestre atua isoladamente, mas somos dependentes de uma comunicação positiva, que ajude cada ser humano a desenvolver seus valores interiores e a crescer espiritualmente, como única forma de cumprirmos a nossa missão

Ser professor é ter sempre palavras de estímulo, de generosidade e de otimismo. A humildade, que é a atitude correta dos sábios, deve ser a constante na transmissão do conhecimento. Este é o esforço e a determinação de cada um para que possamos vivenciar um mundo melhor.

E esta arte de ensinar, o cumprimento da minha missão, da nossa missão, são os valores que me impulsionam a continuar, com entusiasmo, a acreditar nesta juventude e a ter certeza de que atingiremos os objetivos fixados: retribuir com carinho e dedicação tudo que a vida acadêmica nos proporcionou durante estas duas décadas.

Reitero meus agradecimentos a todos que vieram prestigiar esta Solenidade, desejo felicidade ao meu colega titular, Doutor Sérgio Pinto Martins, e espero ter forças para cumprir o que me foi reservado

Muito Obrigado!!

São Paulo, dezembro de 2003. 


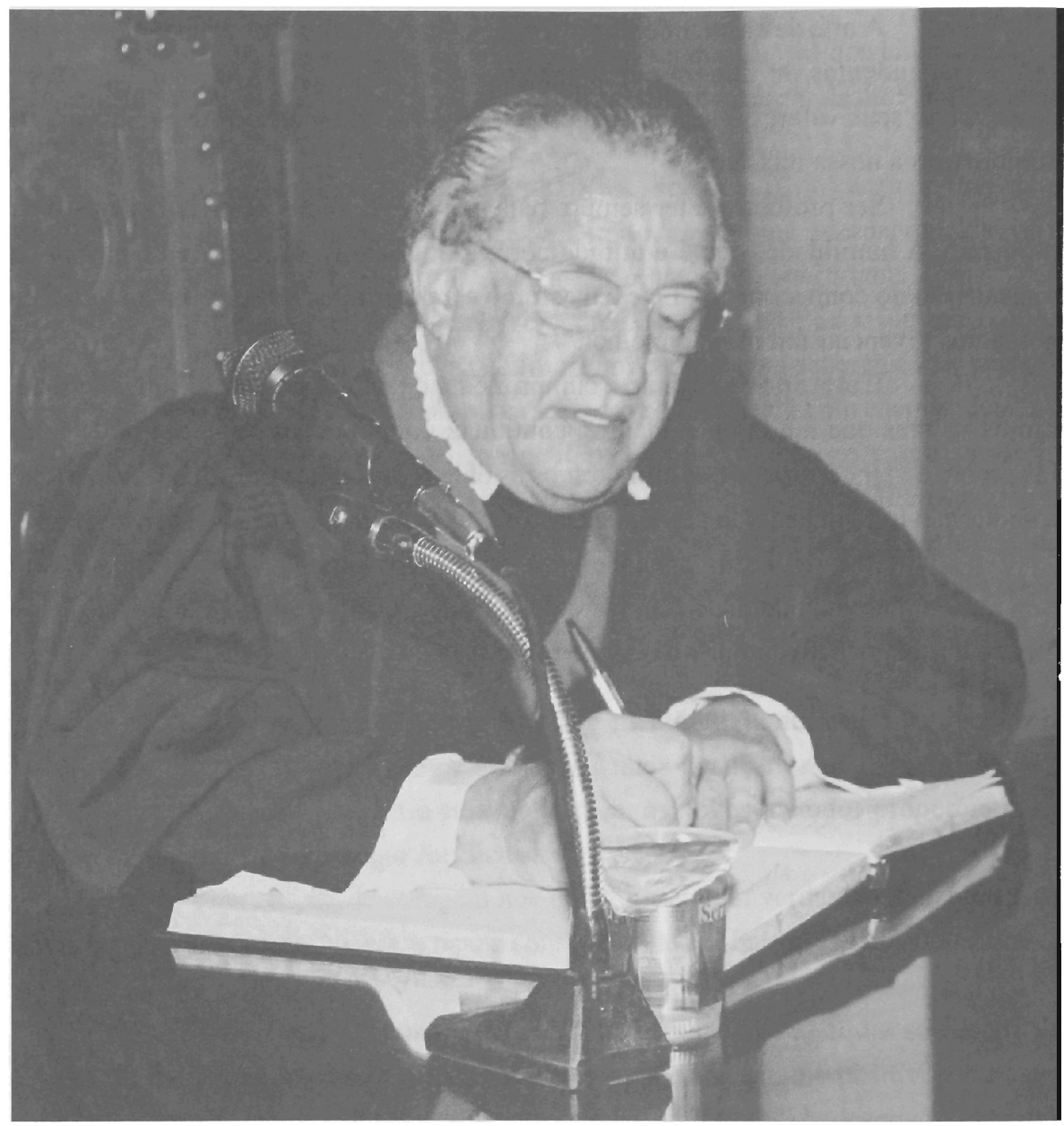

Professor Titular Antonio Luis Chaves Camargo 